\title{
Results of surgical treatment of perforated peptic ulcer
}

\section{Wyniki operacyjnego leczenia przedziurawionego wrzodu trawiennego}

\author{
Wiesław Tarnowski, Krzysztof Bielecki, Piotr Kamiński, Łukasz Janaszek \\ Department of General and Digestive Tract Surgery, Postgraduate Medical Education Centre, Warsaw, Poland
}

Przegląd Gastroenterologiczny 2011; 6 (4): 243-251

DOI: 10.5114/pg.2011.24307

Key words: perforated peptic ulcer, surgical treatment, ulcers' suture.

Słowa kluczowe: przedziurawiony wrzód trawienny, leczenie operacyjne, zszycie wrzodu.

Address for correspondence: Piotr Kamiński MD, PhD, Oddział Kliniczny Chirurgii Ogólnej i Przewodu Pokarmowego, CMKP, Szpital im. prof. W. Orłowskiego w Warszawie, 231 Czerniakowska, 00-416 Warszawa, phone: +48 $226290004,+48225841136$, e-mail: pwkaminski@poczta.onet.pl

\begin{abstract}
Introduction: Effective treatment with $\mathrm{H}_{2}$-blockers and proton pump inhibitors almost removed the necessity of elective surgical treatment of refractory peptic ulcer disease. Life-threatening complications of peptic ulcer still occur and patients with perforated peptic ulcer almost always need surgical treatment.

Material and methods: Seventy-five consecutive patients aged 16-91 years (31 women and 44 men) operated on because of perforated peptic ulcer in our department between 1 January 2001 and 31 December 2009 were studied retrospectively.

Results: The mean age was $51.5 \pm 20.5$ years. Of the $75 \mathrm{pa}$ tients, 34 (45.3\%) had co-morbid disease, 14 (18.6\%) presented with a delay of more than $24 \mathrm{~h}, 16$ (21.3\%) were older than 70 years and 25 (33.3\%) were assessed as ASA grade 3 or more. Postoperative complications occurred in 19 patients (25.9\%). Cardio-pulmonary failure (5 patients) and wound infection (4 patients) were the most common. The mean hospital stay of recovered patients was 7.7 days (3-38). Eleven (14.6\%) patients died. Age above 70 years, presence of comorbid illness, presence of abdominal postoperative complications, American Society of Anesthesiologists (ASA) grade 3 or more, presence of shock on admission and gastric localisation of ulcer were identified as factors increasing risk of mortality.

Conclusions: The incidence of perforated peptic ulcer among elderly patients, females in particular, is increasing. The number of patients with perforated peptic ulcer as the first symptom of peptic ulcer is increasing. Perforated peptic ulcer still involves high postoperative mortality.
\end{abstract}

\section{Streszczenie}

Wstęp: Skuteczne leczenie lekami blokującymi receptory $\mathrm{H}_{2}$ oraz inhibitorami pompy protonowej spowodowało prawie całkowity zanik wskazań do planowego leczenia operacyjnego choroby wrzodowej opornej na terapię. Ciągle jednak występują zagrażające życiu powikłania choroby wrzodowej, a chorzy z przedziurawionym wrzodem trawiennym prawie zawsze wymagają leczenia operacyjnego.

Materiat i metody: Analizowano retrospektywnie wyniki leczenia 75 chorych w wieku 16-91 lat (31 kobiet i 44 mężczyzn) operowanych w Klinice z powodu przedziurawionego wrzodu trawiennego od 1 stycznia 2001 r. do 31 grudnia 2009 r. Wyniki: Średni wiek chorych wynosił $51,5 \pm 20,5$ roku. W grupie 75 badanych u 34 (45,3\%) stwierdzono obecność chorób wspótistniejących, 14 osób (18,6\%) operowano po upływie 24 godz. od wystąpienia objawów przedziurawienia, $16(21,3 \%)$ miało więcej niż 70 lat, a stan ogólny w stopniu ASA 3-5 oceniono u 25 chorych (33,3\%). Powikłania pooperacyjne wystąpiły u 19 badanych (25,3\%). Niewydolność krążeniowo-oddechowa (5 chorych) i zakażenie rany (4 chorych) były najczęstszymi powikłaniami. Średni pooperacyjny pobyt w szpitalu osób wyleczonych wynosił 7,7 dnia (3-38 dni). Zmarło 11 badanych (14,6\%). Wiek powyżej 70 lat, obecność chorób wspótistniejących, obecność śródbrzusznych powikłań pooperacyjnych, stan ogólny chorego oceniony jako 3-5 stopień ASA, obecność objawów wstrząsu podczas przyjęcia do szpitala oraz przedziurawienie wrzodu żołądka były czynnikami zwiększającymi ryzyko zgonu chorego.

Wnioski: Zwiększa się występowanie przedziurawienia wrzodu trawiennego wśród ludzi starszych, zwłaszcza kobiet. Wzrasta liczba osób, u których przedziurawienie wrzodu jest pierwszym objawem choroby wrzodowej. Przedziurawienie wrzodu trawiennego obciążone jest dużą śmiertelnością. 


\section{Introduction}

Non-surgical treatment with the parietal cell $\mathrm{H}_{2}$ histamine receptor blockers introduced in the 1980s as well as treatment with proton pump inhibitors introduced in the 1990s provided prompt direct improvement and recovery in a high percentage of patients and the percentage of relapses within 12 months is low, which dramatically decreased the necessity of elective surgical management in gastric or duodenal ulcer disease. Another achievement in the 1980s in peptic ulcer disease (PUD) was discovery of the aetiopathogenetic role of Helicobacter pylori and introduction of eradication therapy [1, 2]. However, this treatment is not successful in all patients, and lifethreatening complications of PUD in the form of haemorrhage or perforated peptic ulcer (PPU) still occur. Perforated peptic ulcer still constitutes a serious health problem associated with a high percentage of complications and deaths. In Western countries a distinctly decreased number of elective operations as well as, to a lesser extent, operations performed due to haemorrhage or perforation has been observed $[3,4]$. However, in the same period there were some reports stating that the number of operations carried out because of PPU did not change or increased [1, 5]. A growing tendency of developing perforated ulcer in women has also been noted, in elderly age in particular, as well as increasing PPU incidence in patients who were not conservatively treated previously [6].

In the past most surgeons chose definitive procedures in PPU management in order to decrease hydrochloric acid secretion, because reduction of surgery to suturing the perforation was less effective due to a high incidence of PUD relapses, reaching $42 \%$ of patients operated on [7, 8]. At present definitive operations are rarely performed and primary suturing of the perforated ulcer constitutes a procedure of choice. Some surgeons believe that definitive operations are not necessary in the treatment of perforations [9] or are restricted to a selected group of patients [10]. The objective of this work was to assess PPU surgery treatment outcomes as well as to analyse complications and risk factors for death in patients treated in our department.

\section{Material and methods}

The study included 75 patients operated on for PPU in the Department of General and Digestive Tract Surgery, Medical Centre of Postgraduate Education in Warsaw between 2001 and 2009. Patients operated on for gastric neoplasms and pyloric stenosis were excluded from the study. We retrospectively gathered data in regard of gender and age of patients, comorbidity, use of non-steroid anti-inflammatory drugs (NSAIDs), steroids or immunosuppressants, occurrence of shock symptoms on hospital admission, ulcer location, time from the onset of symptoms to the surgery, post-operative complications, duration of hospital stay after the surgery, and number of deaths. The diagnosis was established based on medical history, physical examination, laboratory tests, and X-ray examinations. Commencing the surgery within more than $12 \mathrm{~h}$ of the assumed onset of perforation symptoms was qualified as delayed surgical intervention. Operations were defined as non-definitive then they involved suturing the perforation and suturing a greater omentum flap in the area of the suture line, and definitive operations were in the form of pyloroplasty and vagotomy. Patient's death within 30 days of the surgery or later during single hospital stay was defined as perioperative mortality. The compared parameters were assessed with the test of statistical significance concerning the ratio differences and differences in arithmetic means. Value of $p<0.05$ was assumed as statistically significant.

\section{Results}

Surgical procedures were performed in 75 patients aged 16-91 years, with the mean age of $51.5 \pm 20.5$ years. This group included 44 males and 31 females. The mean age of males was $44 \pm 17.1$ years (range 16-77) and the mean age of females was $62 \pm 21.2$ years (range 21-91). The difference was highly statistically significant $(p<0.001)$. Table I shows age distribution in regard of patients' gender. Only 3 males were over 70, whereas 13 females (41.9\%) were 74 and above. The difference was statistically significant $(p<0.001)$. Compared to patients treated in our department between 1968 and 1979 the group of older patients increased in number considerably. We treated 16 patients aged over 70 (21.3\%)

Table I. Age and gender of patients Tabela I. Wiek i płeć chorych

\begin{tabular}{lcccccccccc} 
Age & $<20$ & $21-30$ & $31-40$ & $41-50$ & $51-60$ & $61-70$ & $71-80$ & $>80$ & Total \\
\hline Female & - & 3 & 5 & 2 & 4 & 4 & 4 & 9 & 31 \\
\hline Male & 5 & 6 & 6 & 13 & 7 & 4 & 3 & - & 44 \\
\hline Total & 5 & 9 & 11 & 15 & 11 & 8 & 7 & 9 & 75
\end{tabular}


and in the 1970s the group of patients of similar age accounted for $8.2 \%$. The difference was statistically significant $(p<0.05)$. Perforated duodenal ulcer was treated in 54 patients (20 females and 34 males) including 12 patients with pyloric perforation. Perforated gastric ulcer located proximally from the pylorus occurred in 21 patients (including 11 females). Patients treated for perforated gastric ulcer were older than patients treated for perforated duodenal ulcer, both in the case of males (mean age was 59.2 vs. 39.6 years respectively) and females (mean age was 66.4 vs. 59.6 years respectively). Distinct seasonality of PPU was not observed.

Medical history suggestive of PUD was taken in 32 cases $(42.7 \%)$ but only in 18 patients (24.0\%) was PUD confirmed by gastroscopy. The majority, 43 patients (57.3\%), did not experience any discomforts which would persuade them to seek medical advice before the ulcer was perforated. The onset of the disease was manifested with sudden abdominal pain most commonly located in the epigastrium in 70 patients (93.3\%). The pain was accompanied by vomiting in 21 patients (29.3\%). Physical examination on hospital admission showed muscular guarding in 68 subjects (90.6\%) and rebound tenderness in 66 patients (88.0\%). Eight of the patients (10.6\%) were admitted with shock symptoms. An abdominal X-ray in the standing position was taken in 71 patients - it allowed the diagnosis of free gas under the diaphragm in 56 patients (78.8\%). In 3 subjects without free gas in the peritoneal cavity gastric examination using gastrographin was carried out - in one patient the examination showed leakage of contrast medium outside the lumen of the gastrointestinal tract. Moreover, in one patient, who initially did not agree to the surgery, the second X-ray image taken after $12 \mathrm{~h}$ showed free gas in the abdominal cavity. In the remaining 17 subjects (22.6\%) the diagnosis was established during laparotomy performed due to peritonitis symptoms.

Medical history revealed that 12 patients were chronic users of NSAIDs and 4 patients had taken steroids for 5-10 years due to rheumatoid arthritis or chronic obstructive pulmonary disease (COPD). In 34 pa- tients (45.3\%) 1 to 4 concomitant diseases were found. The most common included arterial hypertension (12 subjects) and ischaemic heart disease (10 subjects). Moreover, 8 patients had concomitant neoplastic disease: lung cancer in 3 subjects, prostate cancer in 2 subjects, and in single cases melanoma, leukaemia, anal carcinoma, and generalised neoplastic disease of unknown primary site (one patient had both lung cancer and prostate cancer at the same time) -5 of the subjects died.

Table II shows the assessment of the patient's general condition according to the American Society of Anesthesiologists (ASA). The assessment indicates that females treated for PPU presented worse condition than males. The condition of 17 females (54.8\%) was assigned category 3 to 5 according to the ASA scale, whereas the same category was assigned to the condition of 8 males (18.2\%) only. The difference was highly statistically significant $(p<0.002)$.

All the patients were operated on at $2 \mathrm{~h}$ to $120 \mathrm{~h}$ after the onset of perforation symptoms. In most patients (67 cases; $89.3 \%$ ) perforation was sutured with single sutures and the suture line was covered with a fixed greater omentum flap. Moreover, in 6 other patients apart from suturing of the perforation, Heinecke-Mikulicz pyloroplasty (4 subjects) or Jaboulay pyloroplasty (2 patients) was performed. Only in two patients was definitive surgery carried out - a truncal vagotomy and Heinecke-Mikulicz or Jaboulay pyloroplasty. The data are presented in Table III. In 2 cases the surgery of suturing a duodenal ulcer and omentopexy was performed by laparoscopy.

The dimensions of peptic ulcer perforation ranged from $2 \mathrm{~mm}$ to $30 \mathrm{~mm}$, the mean value being $6.7 \mathrm{~mm}$, and the median $5 \mathrm{~mm}$. In 16 patients (21.3\%) the diameter of perforation was at least $10 \mathrm{~mm}$. In 2 patients, who were initially diagnosed with acute appendicitis, appendectomy was performed. Moreover, in 1 patient cholecystectomy was carried out due to concomitant cholecystitis with underlying cholelithiasis.

In 19 patients (25.3\%) post-operative complications occurred, the most common being cardiopulmonary fail-

Table II. General condition of patients assessed according to the scale of the American Society of Anesthesiologists (ASA)

Tabela II. Stan ogólny chorych oceniany wg skali Amerykańskiego Stowarzyszenia Anestezjologów (ASA)

\begin{tabular}{lcccccc} 
ASA & 1 & 2 & 3 & 4 & 5 & Total \\
\hline Female & 5 & 9 & 8 & 6 & 3 & 31 \\
\hline Male & 20 & 16 & 3 & 3 & 2 & 44 \\
\hline Total & 25 & 25 & 11 & 9 & 5 & 75
\end{tabular}


Table III. Surgical treatment depending on time from the onset of PPU symptoms to surgery commencement

Tabela III. Leczenie operacyjne w zależności od czasu, jaki upłynął od wystąienia objawów przedziurawienia do rozpoczęcia operacji

\begin{tabular}{lcccccc} 
Time to surgery [h] & $<6$ & $7-12$ & $13-18$ & $19-24$ & $>24$ & Total \\
\hline Gastric ulcer (suturing) & 5 & 4 & 5 & 2 & 5 & 21 \\
\hline Duodenal ulcer (suturing) & 18 & 13 & 4 & 3 & 8 & 46 \\
\hline Duodenal ulcer (suturing + pyloroplasty) & 2 & & 3 & 1 & 1 & 6 \\
\hline Duodenal ulcer (pyloroplasty + vagotomy) & 25 & 1 & & & 14 & 75
\end{tabular}

ure (5 patients), wound infection (4 patients), pneumonia (3 patients), and renal failure (3 patients).

Three subjects developed suture leakage. Two female patients aged 68 (ASA 3) and 79 (ASA 5) previously treated with steroids for several years due to rheumatoid arthritis were reoperated on and the ulcer suturing was performed again (no signs of healing at the suture site were found intraoperatively). Both patients died on day 14 and 15 following the first surgery. In the third patient, a 77-year-old man with renal failure and melanoma (ASA 4), an attempt of Taylor conservative treatment was made. The patient died on day 14 following the surgery. Another 2 female patients required second surgery. One of those patients, a 52-year-old woman admitted with shock symptoms and operated on at $13 \mathrm{~h}$ of the perforation symptoms onset, whose perforation of $20 \mathrm{~mm}$ in diameter was sutured, underwent reoperation on day two following the first surgery due to persistent peritonitis symptoms - no suture leakage was found and after rinsing the abdominal cavity was closed. In the later postoperative period a successfully resuscitated cardiac arrest occurred. On the following days the patient developed a stroke. The subject died after a 36-day stay in the hospital. Another 80-year-old patient with prior surgery due to pertrochanteric fracture of the femur was admitted to the hospital in relation to a 24-h history of abdominal pain. The X-ray did not show any free gas within the abdominal cavity. Abdominal computed tomography revealed gas in the peritoneal cavity. She was operated on following $4 \mathrm{~h}$ of her stay in the department - the perforation of approximately $7 \mathrm{~mm}$ was sutured. The patient underwent reoperation on day 6 due to a burst abdomen and a subphrenic abscess; she was treated using the open abdomen technique. She underwent 3 relaparotomies in order to rinse the peritoneal cavity. On day 17, following another lavage procedure, the abdominal wall was sutured. The patient was discharged home after 38 days of hospitalisation.

During the post-operative period 11 patients died within 2 to 36 days, with the mean of 9.6 days following suturing of the perforation. Recovered patients stayed in the department for 3 to 38 days with the mean of 7.7 days. The age of deceased patients ranged from 52 to 91 years, with the mean of $74.2 \pm 10.3$ years. The mean age of the recovered patients was $47.6 \pm 19.3$ years. The difference was highly statistically significant $(p<0.0005)$. The mean age of recovered female patients was $58.2 \pm 21.6$ years and the mean age of deceased female patients was $75.1 \pm 12.8$ years. The difference was statistically significant $(p<0.01)$. The mean age of recovered male patients was $41.2 \pm 14.6$ years and the mean age of deceased male patients was $72.5 \pm 4$ years. The difference was highly statistically significant $(p<0.0005)$.

Table IV presents factors influencing perioperative mortality. The data indicate that the following factors increased the risk of death in a statistically significant manner: age above 70, comorbidity, over 12-h delay of the surgical intervention since the onset of perforation symptoms, perforation diameter above $10 \mathrm{~mm}$, perforated gastric ulcer, bad general condition (ASA 3-5), and shock symptoms on admission. The risk of death was elevated with long-term steroid or NSAID therapy.

\section{Discussion}

Treatment refractory gastric and duodenal ulcer disease as well as their complications were common indications for surgical intervention between 1960 and 1985. In the following years, after $\mathrm{H}_{2}$ blockers and, later on, proton pump inhibitors and $H$. pylori antibiotic eradication were introduced, the number of operations started to decline gradually until there was almost a complete lack of elective operations performed due to PUD. During a 20-year observation period at the Surgical Ward of the University Hospital in San Antonio, the mean number of elective operations required because of the ulcer being refractory to conservative treatment dropped from 70 cases annually between 1980 and 1984 to 14 cases annually between 1995 and 1999. But during the last 3 years of the study no elective surgery was performed. In the 
Table IV. Factors affecting perioperative mortality after PPU surgical treatment

Tabela IV. Czynniki wpływające na śmiertelność okołooperacyjną po leczeniu operacyjnym przedziurawienia wrzodu trawiennego

\begin{tabular}{|c|c|c|c|}
\hline Factor & $N$ & Deaths $[\%]$ & Value of $p$ \\
\hline Gender (male : female) & $44: 31$ & 9.1 vs. 22.6 & n.s. \\
\hline Age $(<70:>70)$ & $59: 16$ & 8.5 vs. 37.5 & $<0.005$ \\
\hline Comorbidity (yes : no) & $34: 41$ & 32.3 vs. 0 & $<0.002$ \\
\hline Over 12-h delay of surgical intervention (yes : no) & $33: 42$ & 24.2 vs. 7.1 & $<0.05$ \\
\hline Ulcer location (stomach : duodenum) & $21: 54$ & 33.3 vs. 7.2 & $<0.005$ \\
\hline Perforation diameter $(<10 \mathrm{~mm}:>10 \mathrm{~mm})$ & $59: 16$ & 8.4 vs. 37.5 & $<0.005$ \\
\hline Postoperative abdominal complications (yes : no) & $6: 69$ & 83.3 vs. 8.7 & $<0.001$ \\
\hline NSAIDs (yes : no) & $12: 63$ & 33.3 vs. 11.1 & $<0.05$ \\
\hline Chronic steroid therapy (yes : no) & $4: 71$ & 75 vs. 11.3 & $<0.002$ \\
\hline ASA (1-2) : (3-5) & $50: 25$ & 2 vs. 40 & $<0.001$ \\
\hline Shock on admission (yes : no) & $8: 67$ & 50 vs. 10.4 & $<0.005$ \\
\hline
\end{tabular}

same period the number of emergency operations performed due to haemorrhage decreased by $86 \%$ and the number of operations performed because of PPU went down by $31 \%$ only [3]. In the study concerning PUD treatment in Finland between 1987 and 1999 it was found that the mean annual number of elective operations decreased statistically significantly from 15.7 to 1.7 per 100,000 inhabitants, whereas the number of emergency operations performed as a result of PPU increased significantly from 4 in 1987 to 5.8 in 1999 per 100,000 inhabitants $(p<0.05)$ [1]. A similar tendency was observed in our department. Between 1968 and 1979 a mean of approximately 80 patients a year were operated on for PUD and its complications. Perforated peptic ulcer constituted the reason for surgery in a mean of 6 patients (7.8\%) annually [11]. In the last decade there were no operations performed due to refractory PUD. Peptic ulcer haemorrhages are successfully arrested by injections during gastroscopy and surgical intervention is rarely required -2 patients within the last 5 years. There are 1-2 elective operations performed annually due to pyloric stenosis. However, the number of operations performed for PPU increased - during the study period we operated on 8 patients annually on average. At present most patients operated on for PPU are male [8, 10, 12]. Recently a growing number of perforations has been observed in elderly subjects, women in particular [6, 13]. A similar change has been found in our patients. In the 1970s patients aged over 70 constituted a small (8.2\%) group [11]. In the current study patients over 70 years of age were considerably more numerous - 16 subjects (21.3\%). It seems to be related to common use of NSAID therapy in elderly people, women in particular. Torring et al. studied a large group of 1271 patients with a PPU aged 54-84. Almost half of them (595; 46.8\%) took NSAIDs. Women constituted the majority (67.2\%) of this group [14]. In our group 12 subjects took medications of this class -7 patients were over 70 .

We did not find any distinct seasonality of perforations in our group - most patients (29\%) experienced PPU in winter (December-February) and the smallest group of patients (17\%) in spring (May-June). The difference was not statistically significant. Similar seasonality was observed in India and Hong Kong, where perforations occurred most often in November-February [12]. This is inconsistent with the data regarding occurrence of PPU gathered in Cracow in the period 1991-1995, where an increased number of cases was observed in spring/summer months (May-July) and early autumn (September-October). The difference in incidence between the abovementioned seasons and the other months of the year was statistically significant [15]. However, another study, also conducted in Cracow, which covered the period 1993-1997, did not demonstrate any statistically significant changes in the number of PPU cases in the individual months, quarters or calendar seasons. Nevertheless, a powerful, statistically significant dependence was found between perforation occurrence and days with low atmospheric pressure versus days of increased pressure [16].

As restricting the surgery to suturing of the ulcer involved a high risk of relapse, in the past definitive surgery, which would decrease the hydrochloric acid secretion, was the aim [8, 17]. Easy and quick to perform, simple ulcer suturing was advised at that time as a treatment of choice in perforated duodenal ulcer 
occurring in elderly patients due to increased operational risk as a result of comorbidity and in patients in bad general condition [18, 19].

Since $H$. pylori was discovered, various studies have demonstrated that bacteria eradication decreased the percentage of duodenal ulcer relapses considerably. Enders et al. compared a group of patients a year after ulcer suturing, who received eradication treatment after the surgery, with a group of patients receiving only omeprazole after the surgical procedure. Relapses of duodenal ulceration were statistically significantly less numerous among patients receiving antibiotic therapy than among patients receiving omeprazole (4.8\% vs. $38.1 \%$ ) [9]. Kate et al. demonstrated that a relapse of duodenal ulceration following suturing of the perforation is statistically significantly dependent on $\mathrm{H}$. pylori infection. They believe that bacteria eradication should be advised to all the patients after suturing of the ulcer who were diagnosed with $\mathrm{H}$. pylori infection [20].

It was observed that the incidence of $\mathrm{H}$. pylori infection is lower among patients with perforated duodenal ulcer than patients with uncomplicated PUD. In the latter group the incidence of infection in many reports is nearly $100 \%$. Gilbert et al. found $H$. pylori in approximately $60 \%$ of patients operated on for PPU and in $87 \%$ of patients treated for uncomplicated ulcer. The difference was statistically significant. The investigators believed that the reason for this difference was considerably more common use of NSAIDs in patients operated on for perforated ulcer (56\%) than in patients who experienced uncomplicated PUD (26\%) [21]. Other authors found more common occurrence of $\mathrm{H}$. pylori infection in patients with perforated duodenal ulcer, pyloric ulcer, and ulcer of the pyloric part of the stomach treated by suturing of the perforation and bacteria eradication than in subjects from the control group free of PUD (73.9\% vs. 59.4\%). The difference was not statistically significant $[22,23]$. They concluded that this slight difference did not support the thesis of $H$. pylori's role in the pathogenesis of PPU but the results obtained demonstrated that simple suturing of the perforated ulcer involved a low percentage of PUD relapses $(2.6 \%$ during a 2-year follow-up) provided that $H$. pylori eradication was performed and NSAIDs were not used [22].

We did not investigate the incidence of $H$. pylori infection among our patients. All the patients operated on for duodenal ulcer and most patients operated on for gastric ulcer received eradication treatment on day 4-5 following the surgery. On the first days after the surgery the subjects received IV omeprazole.

In 1990 Nathanson et al. reported on laparoscopic repair, suturing of the perforated duodenal ulcer, and cleaning and rinsing of the peritoneal cavity [24]. In the same year, Mouret et al. published the initial results of laparoscopic perforation treatment by suturing a 'patch' of greater omentum above the perforation and sealing the omentum with fibrinous glue [25-27]. In the following years various laparoscopic techniques were developed for perforated ulcer treatment: the use of sutures with one or three sutures, gelatine sponge and fibrinous glue, fixing the greater omentum around the perforation with a stapler, blocking the perforation with a round ligament of the liver using a gastroscope, and blocking the perforation with part of the greater omentum, also using a gastroscope [7, 17, 26, 28-31].

The most commonly performed laparoscopic procedures include the following: simple suturing of the ulcer, suturing of the ulcer with omentopexy, and omentopexy alone [30]. Lunevicius et al. analysed and reviewed 96 studies on PPU laparoscopic treatment. The review of 12 retrospective studies demonstrated that the mean duration of surgery was $90 \mathrm{~min}$, the mean percentage of complications $10.5 \%$, the mean percentage of conversions $7 \%$, the mean perioperative mortality zero, and the mean duration of hospital stay 7 days. However, a review of 13 prospective studies showed that the mean duration of surgery is shorter (72 $\mathrm{min}$ ), the postoperative complication rate is low $(6 \%)$, the mean percentage of conversions is higher (15\%), and the perioperative mortality is higher as well (3\% on average) [29]. Bertleff et al. conducted a randomised clinical trial to compare results of laparoscopic suturing of the ulcer with open laparotomic suturing. The percentage of conversions was $8 \%$. Patients treated with the open method showed more common postoperative complications as well as a slightly higher number of deaths, but the differences were not statistically significant. The mean duration of laparoscopic surgery was statistically significantly longer than the duration of open surgery (75 min vs. $50 \mathrm{~min}$ ). The authors believed that laparoscopic suturing of the ulcer was more difficult, particularly when the edges of the perforation were infiltrated and fragile. If this is the case, sutures cut the tissues more easily; it is more difficult to drive the needle in at a longer distance from the perforation edge and to make a proper knot. Another reason for the surgery's longer duration is rinsing, because it is time-consuming and aspiration of the fluid reduces pneumoperitoneum. However, the postoperative pain was assessed as statistically significantly less intense by the patients treated laparoscopically [25]. In our group, only 2 subjects underwent laparoscopic surgery.

Postoperative complications occurred in 19 patients (25.3\%). This reflects data from the literature. The complication rate reported in publications ranged from $15 \%$ to $31.5 \%[10,12,25,30,32]$. The most commonly report- 
ed complication was wound infection, occurring in $3-18.5 \%$ of patients $[18,33]$. In our group wound infection developed in $5.3 \%$ of patients. Perforated peptic ulcer still involves high perioperative mortality ranging from $3 \%$ to $42.7 \%$ of patients [ $6,12,14,18,25,34-36]$. In our group 11 patients (14.6\%) died. There was no statistically significant difference between percentages of deaths depending on the patients' gender. A tendency for higher mortality among females was observed [10, 12]. Comorbidity is an important factor affecting outcomes of PPU treatment. It occurs in $7-53 \%$ of patients and $20-33 \%$ of them die after the surgery [10, 12, 32, 33]. Chronic obstructive pulmonary disease constitutes a factor increasing the risk of death considerably. Christensen et al. reviewed treatment outcomes of 2033 patients with perforated ulcer, 210 of whom were treated for COPD before the surgery. Perioperative mortality in this group was $44 \%$ and was statistically significantly higher than in the other 1823 patients [37]. In our group $32 \%$ of patients with comorbidity died $(p<0.002)$.

Another factor which increased the risk of death was the age of patients. Perioperative mortality among patients over 70 years ranged from 25 to $47 \%$ [10, 19, 38]. In our group $37.5 \%$ of patients over 70 died. The percentage of deaths in the younger age group (8.5\%) was statistically significantly lower $(p<0.005)$.

An important factor is the time between the onset of perforation symptoms and surgical intervention. The best recovery rates were obtained when the surgery was performed within $6 \mathrm{~h}$ of the onset of the disease there were no deaths in our group of patients. An over 12-h delay of surgical intervention increases the risk of death by 3-7 times [10, 12, 33, 39]. In our group mortality among patients operated on after more than $12 \mathrm{~h}$ was 3 times higher than among patients operated on earlier $(p<0.05)$.

Patients' general condition assessed according to the ASA scale was a significant risk factor related to unsuccessful treatment outcomes. It was reported that higher ASA categories in patients operated on for perforated ulcer suggest unfavourable prognosis [10, 12]. In our group there were $40 \%$ of deaths among patients whose general condition was assessed as ASA 3-5 ( $p<0.001)$.

It was reported in the literature that chronic NSAID treatment, chronic steroid therapy and chronic use of tramadol prior to ulcer perforation constitute factors considerably deteriorating the prognosis after surgical treatment of the perforation. In Denmark a large group of 1271 patients surgically treated for perforated ulcer were assessed and it was found that mortality among subjects previously treated with tramadol was twice as high and among subjects chronically treated with
NSAIDs was 1.4-1.8 times higher than among patients who did not use those medications $[14,36]$. A study from the same site demonstrated that chronic treatment with glucocorticoids leads to an almost two-fold mortality rate increase among patients operated on for perforated ulcer [40]. In our group, mortality among patients using NSAIDs, and particularly among patients under chronic steroid therapy, was statistically significantly higher than among subjects who did not take those medications ( $p<0.05$ and $p<0.002$ respectively).

Shock symptoms on hospital admission multiply the risk of death (by 14-30 times) due to perforated ulcer [10, $32,33]$. In our group the number of deaths was five times higher among patients admitted to the hospital with shock symptoms compared to the others $(p<0.005)$. Disputes over gastric ulcer treatment still exist. In a study including 77 patients treated over 36 years (1962-1997) better outcomes were obtained among subjects treated by definitive surgery with stomach resection - 1 patient died out of 34 (3\%). These operations were performed in patients in good general condition. Suturing of a gastric ulcer was carried out in patients 10 years older on average and in worse general condition with the APACHE II score statistically significantly higher than among other patients treated by resection. The outcomes were worse -15 out of 40 patients (37.5\%) died [41]. A similar tactic was adopted by Chandra et al. when qualifying low-risk patients for stomach resection and restricting the surgery to suturing of the perforation in higher-risk patients. Perioperative mortality was 6\% and $24.1 \%$ respectively [32]. In Edinburgh in order to improve treatment outcomes a subspecialist department to treat emergency large intestine conditions and a department to treat emergency upper gastro-intestinal tract conditions were established in 2002. After 2.5 years of work the PPU treatment outcomes improved - perioperative mortality dropped statistically significantly from $20.3 \%$ to $10.4 \%$ [35].

\section{Conclusions}

1. Perforated peptic ulcer most often occurs in young males.

2. The incidence of PPU among elderly patients, females in particular, is increasing.

3. Perforated peptic ulcer occurs slightly more often than 30 years ago, despite advanced medications reducing hydrochloric acid secretion as well as $H$. pylori eradication being introduced during this period.

4. The number of patients with PPU as the first symptom of peptic ulcer is increasing - in our group they constituted $57 \%$.

5. Perforated peptic ulcer involves a high perioperative mortality rate $(14.6 \%)$. 
6. Comorbidity, senior age, general condition within ASA 3-5, shock symptoms on hospital admission constitute factors affecting surgical treatment outcomes considerably.

\section{References}

1. Paimela H, Oksala NKJ, Kivilaakso E. Surgery for peptic ulcer today. Dig Surg 2004; 21: 185-91.

2. Noguiera C, Silva AS, Santos JN, et al. Perforated peptic ulcer: main factors of morbidity and mortality. World J Surg 2003; 27: 782-7.

3. Schwesinger WH, Page CP, Sirinek KR, et al. Operations for peptic ulcer disease: paradigm lost. J Gastrointest Surg 2001; 5: 438-43.

4. Sanchez-Bueno F, Marin P, Rios A, et al. Has the incidence of perforated peptic ulcer decreased over the last decade? Dig Surg 2001; 18: 444-8.

5. Rahman MM, Islam MS, Flora S, et al. Mortality in perforated peptic ulcer patients after selective management of stratified poor risk cases. World J Surg 2007; 31: 2341-4.

6. Canoy DS, Hart AR, Todd CJ. Epidemiology of duodenal ulcer perforation: a study on hospital admissions in Norfolk, United Kingdom. Digest Liver Dis 2002; 34: 322-7.

7. Alvarado-Aparicio HA, Moreno-Portillo M. Management of duodenal ulcer perforation with combined laparoscopic and endoscopic methods. Surg Endosc 2004; 18: 1394.

8. Wysocki A. Rozwój metod leczenia przedziurawionego wrzodu trawiennego. Pol Przegl Chir 2003; 75: 1231-6.

9. Enders K, Lam Y, Sung J, et al. Eradication of Helicobacter pylori prevents recurrence of ulcer after simple closure of duodenal ulcer perforation: randomized controlled trial. Ann Surg 2000; 231: 153-8.

10. Kocer B, Surmeli S, Solak C, et al. Factors affecting mortality and morbidity in patients with peptic ulcer perforation. J Gastroenterol Hepatology 2007; 22: 565-70.

11. Kamiński P, Ancyparowicz S, Kawalski A, et al. Bezpośrednie wyniki leczenia przedziurawionego wrzodu trawiennego. Pol Przegl Chir 1981; 53: 1083-90.

12. Arveen S, Jagdish S, Kadambari D. Perforated peptic ulcer in South India: an institutional perspective. World I Surg 2009; 33: 1600-4.

13. Higham J, Kang JY, Majeed A. Recent trends in admissions and mortality due to peptic ulcer in England: increasing frequency of haemorrhage among older subjects. Gut 2002; 50: 460-4.

14. Torring ML, Riis A, Christensen S, et al. Perforated peptic ulcer and short-term mortality among tramadol users. Br J Clin Pharmacol 2007; 65: 565-72.

15. Wysocki A, Kamiński W, Krzywoń J. Przedziurawienie wrzodu trawiennego w zależności od pór roku. Przegl Lek 1999; 56: 189-91.

16. Budzyński P, Pogoda W, Pogodziński M. Sezonowość i wpływ dobowych wahań ciśnienia atmosferycznego na występowanie ostrych powikłań choroby wrzodowej żołądka i dwunastnicy. Przegl Lek 2000; 57: 611-3.

17. Lau WY, Leow CK. History of perforated duodenal ulcers. World J Surg 1997; 21: 890-6.
18. Gutierrez de la Pena C, Marquez R, Fakih F, et al. Simple closure or vagotomy and pyloroplasty for the treatment of a perforated duodenal ulcer: comparison of results. Dig Surg 2000; 17: 225-8.

19. Blomgren LG. Perforated peptic ulcer: Longterm results after simple closure in elderly. World J Surg 1997; 21: 412-4.

20. Kate V, Ananthakrishnan N, Badrinath S. Effect of Helicobacter pylori eradication on the ulcer recurrence rate after simple closure of perforated duodenal ulcer: retrospective and prospective randomized controlled studies. Br J Surg 2001; 88: 1054-8.

21. Gisbert JP, Legido J, Garcio-Sanz I, et al. Helicobacter pylori and perforated peptic ulcer. Prevalence of the infection and role of non-steroidal anti-inflammatory drugs. Digest Liver Dis 2004; 36: 116-20.

22. Rodriguez-Sanjuan JC, Fernandez-Santiago R, Garcia RA, et al. Perforated peptic ulcer treated by simple closure and Helicobacter pylori eradication. World J Surg 2005; 29: 849-52.

23. Chabik K, Grzebieniak Z. Zakażenia Helicobacter pylori u chorych z pękniętym wrzodem żołądka i/lub dwunastnicy operowanych metodą prostego zszycia. Pol Przegl Chir 2002; 74: 420-9.

24. Nathanson LK, Easter DW, Cuschieri A. Laparoscopic repair/peritoneal toilet of perforated duodenal ulcer. Surg Endosc 1990; $4: 232-3$.

25. Bertleff MJOE, Halm JA, Bemelman WA, et al. Randomized clinical trial of laparoscopic versus open repair of the perforated peptic ulcer: the LAMA trial. World J Surg 2009; 33: 1368-73.

26. Siu WT, Chau CH, Law BKB, et al. Routine use of laparoscopic repair for perforated peptic ulcer. Br J Surg 2004; 91: 481-4.

27. Kirshtein B, Bayme M, Mayer T, et al. Laparoscopic treatment of gastroduodenal perforations. Surg Endosc 2005; 19: 1487-90.

28. Song KY, Kim TH, Kim SN, et al. Laparoscopic repair of perforated duodenal ulcers: the simple "one-stitch" suture with omental patch technique. Surg Endosc 2008; 22: 1632-5.

29. Lunevicius R, Morkevicius M. Management strategies, early results, benefits, and risk factors of laparoscopic repair of perforated peptic ulcer. World J Surg 2005; 29: 1299-310.

30. Lam PWF, Lam MCS, Hui EKL, et al. Laparoscopic repair of perforated duodenal ulcer. Surg Endosc 2005; 19: 1627-30.

31. Lee FYJ, Leung KL, Lai PBS, et al. Selection of patients for laparoscopic repair of perforated peptic ulcer. Br J Surg 2001; 88: 133-6.

32. Chandra SS, Kumar SS. Definitive or conservative surgery for perforated gastric ulcer? An unresolved problem. Int J Surg 2009; 7: 136-9.

33. Testini M, Portincasa P, Piccini G, et al. Significant factors associated with fatal outcome in emergency open surgery for perforated peptic ulcer. World J Gastroenterol 2003; 9: 2338-40.

34. Sarosi GA, Jaiswal KR, Nwariaku FE, et al. Surgical therapy of peptic ulcers in the 21st century: more common than you think. Am J Surg 2005; 190: 775-9.

35. Robson AJ, Richards JMJ, Ohly N, et al. The effect of surgical subspecialization on outcomes in peptic ulcer disease complicated by perforation and bleeding. World I Surg 2008; 32: 1456-61. 
36. Thomsen R, Riis A, Munk E, et al. 30-day mortality after peptic ulcer perforation among users of newer selective Cox-2 inhibitors and traditional NSAIDs: a population based study. Am J Gastroenterol 2006; 101: 2704-10.

37. Christensen S, Thomsen RW, Torring ML, et al. Impact of COPD on outcome among patients with complicated peptic ulcer. Chest 2008; 133: 1360-6.

38. Wysocki A, Bęben P. Type of surgery and mortality rate in perforated duodenal ulcer. Pol Merkuriusz Lek 2001; 11: 148-50.

39. Sowula A, Kabziński A, Fryc B. Nietypowy obraz kliniczny przedziurawionego wrzodu trawiennego dwunastnicy. Pol Przegl Chir 2006; 78: 216-24.

40. Christensen S, Riis A, Norgaard M, et al. Perforated peptic ulcer: use of pre-admission oral glucocorticoids and 30-day mortality. Alim Pharmacol Ther 2006; 23: 45-52.

41. Wysocki A, Biesiada Z, Bęben P, et al. Perforated gastric ulcer. Dig Surg 2000; 17: 132-7. 